\author{
Jerzy Sierociuk \\ Adam Mickiewicz University in Poznań \\ Institute of Polish Philology \\ ORCID: 0000-0001-9069-6117; e-mail: jasier@amu.edu.pl
}

\title{
Dialectal diminutives in a system and a text
}

\begin{abstract}
The article is an attempt at verifying the general opinion about "a vast multitude" of diminutives in Slavic languages, including dialects. An analysis has been carried out of texts recorded by Z. Sobierajski in 1951-1953 and published in a volume of slightly more than 200 pages of texts from 11 locations in western Wielkopolska region (Sobierajski, 1985).

Contrary to the expectations, the number of diminutives in these texts is negligible. They do not represent more than $0.5 \%$ of the registered word forms (whose total number in the volume amounts to 62,711). What is surprising is the redundant, surplus expression of 'smallness' by means of the MAŁY (small) type. MAŁY + a diminutive appeared 38 times thus representing $61.29 \%$ of the MAŁY lexeme in the texts.
\end{abstract}

Key words: dialectal word formation, dialectal diminutives, system of dialectal word formation, diminutives in a dialectal text.

\begin{abstract}
Abstrakt: Deminutiva gwarowe w systemie i w tekście. Artykuł jest próbą weryfikacji ogólnego przekonania o „ogromnym bogactwie” deminutivów w językach słowiańskich, w tym kontekście także w gwarach. Oglądowi poddane zostały teksty nagrane przez Z. Sobierajskiego w latach 1951-1953 i opublikowane w tomie zawierającym nieco ponad 200 stron tekstów z 11 miejscowości zachodniej Wielkopolski (Sobierajski 1985).

Wbrew oczekiwaniom deminutiva pojawiają się w tych tekstach w ilościach śladowych, liczba ich tekstowych użyć nie przekracza 0,5\% zarejestrowanych słowoform (tych w całym tomie jest 62 711). Zaskakuje natomiast redundantne, naddane wyłożenie 'małości' typem MAŁY. MAŁY + deminutivum pojawiło się 38 razy, co stanowi 61,29\% użyć tekstowych leksemu MAŁY.
\end{abstract}

Wyrazy kluczowe: słowotwórstwo gwarowe, deminutiva gwarowe, system słowotwórstwa gwarowego, deminutiwa w tekście gwarowym.

This article presents an analysis of the occurrence of diminutives in dialects which are regarded "the most universal language category (...). They occur in languages which belong to various language families and groups, spoken by nations with a different cultural and civilisation background" (Heltberg 1964, 93).

The quoted researcher has ventured other opinions; following a closer look, some of these assumptions call for tackling the issue. She wrote: 
All Baltic and Slavic languages have a vast [bold print - JS] multitude of diminutive formations, hypocorisms and augmentatives. Wide use and a large number of word formation opportunities, coupled with entire grades of shades make diminutives very important rhetorical terms of expression in these languages (Heltberg 1964, 94).

In the context of dialects, the statement about a "vast multitude" of diminutives is in conflict with field experience. Irrespective of the research area, the following utterances are very frequently recorded:

Q: Jeśli ktoś jest wzruszony, to mu z oczu płyną ...

A: nie wim jak to sie mówi ... nie wim ... zy (!) ...

Q: Mała tza.

A: nie wim jak to mówić ... tza to tza ...

Q: A mala lza?

A: mała tza ... bo ja wim? ... tezka ...

Q: Mała sosna.

A: sosinka ... taka mała sosinka ...

(Boruja Kościelna, Nowy Tomyśl county and commune; informant born in 1913; recording from 2001).

\section{$* * *$}

Q: Co się pojawia nad palącym się drewnem?

A: nó ... co sie może pojawić ... dym jak sie pojawia ... znaczy sie skry ... no ... ogiń sie pojawia ... nie ... pomienie ... no ...

Q: Duży płomień.

A: duży pomiń nie wim ...

Q: A maly?

A: nie wim ...

Q: Mały płomień ...

A: to iskra ... nie ...

Q: A płomyczek?

A: to tyż tam by mogło być ... ale czy my tam na to mówili jakoś? ...

(Czechel, Gołuchów commune, Pleszew county; informant born in 1952; recording from 2008).

These two examples come from different dialects of the Wielkopolska dialect. It is not an indication that this type of utterances is unique to that area. In the subsequent parts of the analysis, I refer to the area of Łuków and recordings of dialects from the historical border between Lesser Poland and Masovia. The structure of these dialects is also affected by the location on the borderland of Polish (i.e. a West Slavic language) and Ukrainian and Belarusian (i.e. an East Slavic language) language areas.

Materials from two very distant dialectal complexes (the dialects of the Łuków area represent the south Masovia dialect) will allow to indicate features which are not determined regionally. Notably, dialectology continues to analyse data labelled with 
their spatial (territorial) location and, more and more frequently, time location (taking into account the informants' age).

Before I proceed with an analysis of the material, let me discuss the idiosyncrasies of dialects which, in my opinion, are of importance.

Unlike the general language which exists predominantly in the written form, ours is a case of a spoken language, upholding the oral tradition. This "life" of dialects was significant when a majority of their speakers were illiterate. Therefore, the rules which in a written language are referred to as norms, operated differently. Consequently, dialects do not comply with standards achieved by all types of grammars (or the entire correctness system) in the writing cultures. When discussing the specificity of oral language, W.J. Ong wrote: "An oral culture has no vehicle so neutral as a list" (Ong 1992, 42); "Oral cultures tend to use concepts in situational, operational frames of reference that are minimally abstract in the sense that they remain close to the living human lifeworld" (Ong 1992, 48-49). And, finally, the most important statement in this context:

Oral cultures of course have no dictionaries and few semantic discrepancies. The meaning of each word is controlled by what Goody and Watt (...) call 'direct semantic ratification' that is, by the real-life situations in which the word is used here and now (Ong 2002, 46).

The above determinants largely impact the need of a specific approach to the research basis. A dialectologist who has at his/her disposal even a substantial collection of territorial registrations (texts) cannot be certain that all the phenomena characterising a specific dialect have been recorded. I have covered the subject in an analysis of a collection of over 200 pages of Dialectal texts from western Wielkopolska region by Z. Sobierajski (Sobierajski 1985) where I pinpointed that the (extensive) book lacks the fundamental features defining west Wielkopolska dialects (Sierociuk 2012a). I will make more references to Z. Sobierajski's texts.

The previously quoted examples from Wielkopolska seem to indicate the interlocutors' problems with creating diminutives. These fragments of conversations were targeted at obtaining the persistance of diminutives (and partly augmentative forms). Therefore, an attempt was made to "gain insight into the system" of the dialect. The aim was to validate the statements documenting the persistence of specific word-formation processes and the productivity of the specific diminutive formants.

Let's take a look at selected examples documenting the phenomenon in question:

\section{Q: Czy jeszcze obecnie używają kosy?}

A: do siana jeszcze nie ... jakiś kawałeczki tak ... mate obszary to koso ...

Q: Półokrągłe metalowe narzędzie do ręcznego wycinania roślin.

A: sierp ... a no sierp ... zapomniatam ...

Q: Czy jeszcze obecnie używane są sierpy?

A: nie ... w matych ilościach ... do żen cia (!) dzieś w ogródku ... czy tak ...

(Gręzówka, Łuków county; informant born in 1937; recorded in 2017). 
Q: Jak robi się stogi właśnie?

A: stogi sie robi? ... jes taki dlugi dlugi dronżek ... wkopany w ziemie lekko ... i na około ... jaki chcesz tyn stóg zrobić ... czy duży czy mały ... ile tam siana masz ... i do samego końca ... od samego końca jes szerzy ... późnij tak coraz we żej ... coraz wenżej ... i taki czubek zostaje tylko ... przy samym tym dro ${ }^{n} \dot{k} k$...

(Gręzówka, Łuków county; informant born in 1957; recorded in 2017).

$* * *$

Q: $\mathbf{Z}$ jakich części składa się radło?

A: ma lemiesz taki maty ... i odktadnie takie ...

Q: Czym się różni radto od pluga?

A: plugim sie orze ... a redtem sie robi rzon dki ...

(Brzozowica, Radzyń Podl. county; informant born in 1940; recorded in 2017).

The above examples illustrate what is confirmed in larger dialectal corpora; in order to determine if we are dealing with diminutive meaning we need more field studies - vide: "ogródek", "dtugi dtugi dron'zek", "rzondki". Field experience shows that these forms cannot be labelled as diminutives. On the other hand, there are also examples of communicating "smallness" with lexical means: "mały" (small); vide: maty lemiesz. Field material also provides evidence of the persistence of examples which indicate unambiguously that not every noun can be a basis for diminutive derivation:

Q: Jak przygotowywano kosę, żeby ścinane zboże "ladnie się układało"?

A: no jak? ... to musi bydź dobrze naostrzona ... i trzeba tak kosiskiem operować ... żeby mate pokosy ... bo jak duży pokos weźmiesz to nie ściongniesz ... a jak mały pokos ... mnijszy pokos ... to sie lepiej uktada pokos ... (Gręzówka, Łuków county; informant born in 1957; recorded in 2017).

However, this issue is not a part of the analysis presented in this article; here I only draw attention to it.

To make the picture complete, let me add a different example: my mieli $w$ kuchni takie małe "okno ... (Bytyń, Szamotuły county; informant born in 1931) where one could expect a diminutive form.

The example below shows an interesting phenomenon:

Q: Proszę opisać jak wygląda soczewica, i co się z nią tradycyjnie robilo?

A: suszyło sie ... to so małe stroncky (!) ... suszyło sie ... i to sie późni młóciło ...

Q: Jak wygląda ta soczewica?

A: to nieduże stro ${ }^{n} c z k i$ so ... i ona wyglon da tak ... to co sie pierogi robi nieraz ... mniejsza

... dużo mniejsza od tego ...

Q: Od grochu?

A: od grochu ... może tubinu nawet ... (Burzec, Łuków county; informant born in 1937; recorded in 2017). 
This is a situation dramatically different from the maty lemiesz case where the change in size is communicated only on the lexical level: maty. It seems (and lack of field experience confirms it unambiguously) that this is an example of limiting the derivative potency; in the dialects under scrutiny, no derivative of lemiesz occurs. In the latter example, the same lexical element is placed next to an evident diminutive form: mate stron cky, replaced by a another variant: "nieduzy". This is therefore an interesting example of redundancy, a semantic surplus to which W.J. Ong referred in the following way:

Since redundancy characterizes oral thought and speech, it is in a profound sense more natural to thought and speech than is sparse linearity. Sparsely linear or analytic thought and speech are artificial creations, structured by the technology of writing (Ong 2002, 39).

In the examples above, "small size" is expressed in two ways: the derived form is somewhat reinforced in a lexical way (there are frequent situations of doubling the lexical element: nóm mama chleb ... taki mały mały chlebeg upiekła ... (Bytyń, Szamotuły county; informant born in 1931); I will discuss it further in the article.

The materials in question contain specimens representing specific usage of the lexical element małe dzieciory [Bytyń, Szamotuły county; informant born in 1928].

Therefore, if we top the above list of formants recorded in various dialect-oriented publications (including Atlas języka i kultury ludowej Wielkopolski - AJKLW), the resulting picture will nevertheless be partial. We know that Wielkopolska region dialects include a diminutive formant -yszek (type: kawałyszek, wianuszek) and that the area is an arena of competition between the diminutive formants -ik and -ek (type: wózik // wózek; płocik // płotek). However, having read the mentioned publications we will be none the wiser about the actual usage (persistence) of the word formation category of our interest by speakers of dialects; that knowledge is fragmentary (cf. Sierociuk 2012c). On the other hand, we should consider the specific property of spoken texts (Sierociuk 2012b) - they lack many features typically regarded markers of specific dialects, features defining a specific dialect (more in Sierociuk 2012a).

A question arises: do dialectal diminutives share the characteristics of the general, written language?

K. Kleszczowa referred to these considerations as follows:

Diminutives are a word-formation category revolving around a modification of the object's features or the intensity of the notion inscribed in the noun. Just like the inflection-based category of the degree, diminutives are within this scale: a word indicating a neutral object with respect to size - a word smaller than the preceding one. This is therefore an act of comparison rather than mere indication of a small size (Kleszczowa 2015, 160).

The above statement will serve as a basis for excerpting diminutives from texts provided by over a dozen informants from west Wielkopolska. For the purpose of the analysis, I have selected the aforementioned "Teksty gwarowe z zachodniej Wielkopolski" by Z. Sobierajski (Sobierajski 1985) which, following preliminary treatment, have been included into the material corpus of a dictionary of (ethno)dialects in Wielkopolska, 
developed in the Dialectology Laboratory of Adam Mickiewicz University in Poznań. This collection of over 200 pages of text contains utterances by inhabitants of 11 villages from an area fairly homogenous with respect to dialects and registered mainly in 1951-1953. The texts were obtained from informants born in the late $19^{\text {th }}$ and the early $20^{\text {th }}$ centuries; therefore they document a dialect from a time when it was still slightly affected by external factors. Notably, it is the oldest available register of dialects from that area of this size.

The collection of dialectal texts taken into consideration in this article contributes in total 62,711 dialectal word forms. When an electronic version of the corpus was being developed, first all the texts were typed in a simplified transcription and, later on, all the forms in the explorer's questions were deleted. Next, in the corpus information like the informant's year of birth, his/her initials, place of residence (recording), the day of the recording and the page in the printed collection was attributed to each dialectal word form. At the same time, each usage contains a relevant, multi-word context (an equivalent fragment of the continuous text) ${ }^{1}$.

The material from west Wielkopolska contains examples like $p^{u} O^{e}$ pó $k^{u}$ opy wióży$m y^{j}$ wi $^{n}$ ksze sno pki potym, a te mate snopki sóm dali (SobZWp87²); A wtedy do piro wión że gó sie $w$ takie małe snopeczki $i p^{u} o^{e} t y m$ ustowio sie takie małe myndylki. W tych myndylkach przynajmni jeszczy tydzień stoji (...) (SobZWp108); ludzi - którzy mieli małe chatupki (SobZWp86).

This is another case where diminutives are not only expressed by word formation. What is more, the material excerpted from the collection (subjected directly to analysis) requires some comment: there are many forms there which cannot be deemed diminutives although in special situations a speaker of a dialect may attribute this meaning to them (cf. the above statements by W.J. Ong). A case in point is the type pyrka which in Wielkopolska dialects is frequently alternated with pyra. Pyrka simply means a 'potato' rather than a 'small pyra' (te stare króliki pasimy "o ${ }^{e} w s y m$, pyrkami $i$ sianym (SobZWp117); "ozili my pyrki z puola. Te pyrki buty na polu przykryte m"ocno ze zimióm (SobZWp105)). Likewise, lack of a diminutive function is reflected in examples like koszyk, worek etc. (my po kolana hakali $i$ do koszyków $i$ do worków sypali (SobZWp140)).

K. Kleszczowa commented on this situation:

The problems in evaluating the value of the diminutive word form stem primarily from the multiple functions of the formants which create the value. Of course not all the $-k a$, -ek functions or the $-k o$ function are of significance to the considerations (Kleszczowa 2015, $161)$.

Very frequently, in this situation we deal with formal diminutives which, as detailed research shows, can also be subjected to a cartographic analysis (Kloferová 2004).

\footnotetext{
${ }^{1}$ For the sake of this article, a parallel corpus of Wielkopolska dialects has been reviewed containing now more than 1,500,000 word forms (dialectal usage).

2 SobZWp is a source abbreviation beyond bibliographic data, it also contains the page number; hence SobZWp87.
} 
Let me therefore proceed with issues referred to in the second part of the article's title - diminutives operating in a dialectal text. I should also comment on K. Heltberg's opinion on a "vast multitude" of these formations. In this situation, a question arises: how frequent are diminutives in dialectal texts?

Z. Sobierajski's texts from west Wielkopolska include:

- the -yszek formant confirmed in total 4 times (czepyszek, garnyszek, rzymyszek - the latter twice) and this formant is widely recognised as "typical" of Wielkopolska dialects;

- the -oszek formant, in total confirmed 3 times, where one derivative is preceded by the word kónsek '(a small) bite'; these are: dziecioszek and chleboszek (and once kónsek chleboszka);

- the -aszek formant, confirmed four times in robaszek.

(Due to the regional characteristics), the -eczek formant (bocheneczek, szkopeczek, wianeczek), confirmed five times, provides a specific context; however, once a derivative with this formant is accompanied by an adjective (mały snopeczek).

This very list proves that diminutives are not highly represented in the text. On the other hand, the list does not give an indication of the general situation.

The lists compiled with reference to the corpus containing the word forms from Z. Sobierajski's collection of texts allow to shed some light on the issue.

Therefore, in a collection of dialectal utterances published on more than 200 pages, the respondents used word forms 62,711 times. The diminutives of our interest or ones that should be considered in this context included:

- 208 diminutives where the group includes derivatives which, in a specific dialect, have units that could be at the basis of the derivation process; this amounts to $0.3316 \%$ of the text;

- 29 examples that could be deemed formal diminutives $-0.046 \%$ of the text.

Let me also refer to other data, namely examples with multi-functional -ek, $-k a$ etc. formants. I have counted 646 of them which represents $1.03 \%$ of the text.

The above data are not impressive. Obviously, they should be confronted with at least two sets: a corpus of written texts (preferably by authors from Wielkopolska) with respect to the persistence of diminutives. On the other hand, it would be very useful to present "statistical" analyses of similar texts (where the regional identity of dialectal affinity has been maintained).

Nevertheless, this analysis provides insight into the idiosyncrasy of dialects, in this case dialects of west Wielkopolska. However, some peculiarities occurred also in materials depicting other dialects (here, dialects from Łuków area in eastern Poland). It seems that dialects from the general area of Poland share a redundant, surplus display of 'small size' by means of the MAŁY (small) type (see e.g. mate stro ${ }^{n} c k y$ ).

The textual use of the MAŁY lexeme in the context of using diminutives also calls for a closer look. The corpus (west Wielkopolska corpus) includes:

- MAŁY (in various forms of the gender) occurring 62 times, while the cluster

- MAŁY + diminutive occurred 38 times; this represents $61.29 \%$ of the textual usage.

What is interesting in this list is (barely) three occurrences of the regional form MAŁKI (małki synek - SobZwP126; matki synuś - SobZWp127 and małkie gón sión$^{n} t k a$ 
- SobZWP126) next to a diminutive; however, these are the only contexts of the textual use of this form of an adjective. It is difficult to determine unambiguously if this form is related in the texts to diminutives; nevertheless, the phenomenon itself deserves more attention in the future.

What is more, the comments presented here clearly confirm that the ultimate picture of the complexity of word-formation processes (and it seems unimportant if it is true only for dialects) to a large extent depends on the way in which the material has been obtained. Focusing exclusively on a description of examples recorded in the course of special explorations does not allow to identify the degree of their persistence (here: rare) in the entire linguistic environment. When examining dialectal phenomena, idiolects should also be taken into consideration as in some situations (with a limited number of informants), they may blur the picture. An analysis of relatively large corpora proves unambiguously that in this type of research the generation factor is of importance. The available modern research methods confirm it beyond any doubt (see Sierociuk 2015).

A confrontation of the examples referred to above is also evidence that it is hard to discuss the specificity of dialectal word formation with respect to data obtained during explorations for the purpose of atlases. In general, the interest in the complexity of word-formation elements grows as synchronous word formation occurs (here, M. Honowska's work Ewolucja metod polskiego słowotwórstwa synchronicznego ( $w$ dziesięcioleciu 1967-1977) [1979] is of great importance). In a majority of dialectological questionnaires (especially the earlier ones), word-formation issues are treated marginally. It is also the case with the materials obtained for the AJLKLW where word formation is not largely represented: out of 645 questions in volume I, including vocabulary, inflection, word formation, there are 123 references to word building although there are also questions definitely exceeding proper word forming like: "Are formations... still in use?" (Sobierajski 1972). The word-forming structure of selected units was frequently presented with reference to an analysis of specific lexemes, dictionary entries. Very frequently, a "habit" from analyses of general language material prevails where an assumption is adopted that any unit with a transparent structure includes a word which is a starting point for the derivation. There is also an indirect assumption that similar relations rule dialects. As it happens, a proper description of the processes of dialectal word formation requires simultaneous access to an entire derivative pair: the derivative and the word which is a word-forming basis. In a dialectal environment, these relations are often non-existent. From the point of view of word-formation relations observed in a dialectal environment, sometimes (e.g. in Wielkopolska dialects) kosiarz will be an indivisible word because what a kosiarz (haymaker) does is sieczenie (cutting); therefore the relation between kosiarz and siec does not document the word-formation relation (Sierociuk 2001; Sierociuk 2003).

One final remark: I do realise that the material subjected to statistical analysis represents one type of dialects. As we know, in dialectology taking into account the territorial diversity lies at the heart of this discipline of science. In this situation, we should assume that, also in this respect, there may be specific differences between dialects of 
various dialectal complexes. However, field experience proves that, while these differences should be considered, the results of the analyses will remain within the same ranges*.

\section{Bibliography}

AJKLW (1979-2005), Atlas języka i kultury ludowej Wielkopolski, Z. Sobierajski, J. Burszta (ed.), t. I-VI, Wrocław-Warszawa-Krakow-Gdańsk-Lódź, Z. Sobierajski (ed.), vol. VII-XI, Wrocław (et al.), Poznań.

Heltberg J. (1964), O deminutywach i augmentatywach, "Prace Filologiczne", vol. XVIII, part 2. pp. 93-102.

Honowska M. (1979), Ewolucja metod polskiego stowotwórstwa synchronicznego (w dziesięcioleciu 1967-1977), Wrocław.

Kleszczowa K. (2015), Neutralizacja deminutywności w polskich derywatach, [in:] I. Stramljič Breznik (edit.), Manjšalnice v slovanskih jazikih: oblika in vloga. Деминутивы в славянских языках: форма и роль. Diminutives in Slavic Languages: Form and Role, Maribor-Bielsko-Biała-Budapest-Kansas-Prague, pp. 159-169.

Kloferová S. (2004), Svazky izoglos v Českém jazykovém atlase: formální deminutiva, [in:] Život s morfémy. Sbornik studií na počest Zdenky Rusínové, Brno, pp. 101-108.

Ong W.J. (1992), Orality and Literacy. The Technologizing of the Word, Routlage, London and New York 2002.

Sierociuk J, (2001), Założenia metodologiczne badań słowotwórstwa gwarowego, [in:] Gwary dziś. 1. Metodologia badań, J. Sierociuk (ed.), Poznań, pp. 153-160.

Sierociuk J, (2003), Słowniki gwarowe a możliwości opisu gwarowego słowotwórstwa, [in:] Gwary dziś. 2. Regionalne stowniki i atlasy gwarowe, J. Sierociuk (ed.), Poznań, pp. 249-255.

Sierociuk J. (2012a), Cechy definicyjne gwar w języku mieszkańców wsi, [in:] Z polskich studiów slawistycznych, series XII. Językoznawstwo. Works for the $15^{\text {th }}$ International Congress of Slavic Researchers in Minsk 2013, Warszawa, pp. 159-166.

Sierociuk J. (2012b), Stowotwórstwo tekstów oralnych, [in:] J. Sierociuk (ed.), Stowotwórstwo słowiańskie: system i tekst. Prace Komisji Stowotwórczej przy Międzynarodowym Komitecie Slawistów. Series 13, Poznań, pp. 335-345.

Sierociuk J. (2012c), Specyfika stowotwórstwa gwarowego w świetle danych korpusowych, [in:] Б. Ћорић, Р. Драгићевић (edit.), Творба речи и юени ресурси у словенским езицима. Зборник радова са четрнаесте међународне научне конферениије Комисије за творбу речи при Међународном комитету славистов, Београд 2012, pp. 331-340.

Sierociuk J. (2015), Na ile w badaniach językowych można mówić o pokoleniu?, [in:] E. Wierzbicka-Piotrowska (ed.), Dialog pokoleń w języku potocznym, w języku wsi $i$ miast, $w$ literaturze, w publicystyce, $w$ tekstach kultury, Warszawa, pp. 41-50.

Sobierajski Z. (1972), Kwestionariusz do Atlasu języka i kultury ludowej Wielkopolski, part I: Stownictwo - Fonetyka - Stowotwórstwo, Q 1-645 (collaborators: M. Gruchmanowa, H. Nowak, Z. Zagórski); part II: Deklinacja - Koniugacja - Składnia, Q 646-1380 (collaborators:

* This is a slightly modified version of the text: Deminutiva gwarowe $w$ systemie $i w$ tekście, [in:] "Z Polskich Studiów Slawistycznych", series 13, volume 2. Językoznawstwo, Zbigniew Greń (ed.), Prace na XVI Międzynarodowy Kongres Slawistów w Belgradzie 2018, Poznań 2018, pp. 273-282. 
M. Gruchmanowa, H. Nowak); part III: Etnographica, Q 1381-1953 (supplemented by T. Wróblewski); part IV: Ilustracje, Poznań.

Sobierajski Z. (1985), Teksty gwarowe z zachodniej Wielkopolski, Wrocław-Warszawa-KrakówGdańsk-Lódź. 